\title{
Analysis of Building Load and Energy Consumption for Pingyi Passive and Ultra Low-Energy Consumption Science Museum
}

\author{
Wenyin Song ${ }^{1, a}$, Zhao Wang ${ }^{2, b}$ \\ ${ }^{1}$ Department of Green Building, Shandong Provincial Academy of Building Research, Jinan, 250031, \\ China \\ ${ }^{2}$ Department of Green Building, Shandong Provincial Academy of Building Research, Jinan, 250031, \\ China \\ aemail: nethardtsong@163.com, bemail:sdjkt@163.com
}

Keywords: Passive and Ultra Low-Energy Consumption Building; Load and Consumption Analysis; Annual Simulation Design

\begin{abstract}
The "passive house” was first presented by Prof. Adamson (Lund University, Sweden) and Dr. Wolfgang Feist (Germany) in 1988. Nowadays, "passive house” has been widely used as a kind of a low-energy consumption and high comfort energy saving building around the world. In 2014, the Passive and Low-Energy Consumption Green Building Memorandum of Understanding has made between Shandong Provincial Housing and Urban-Rural Development Bureau and Deutsche Energie-Agentur (DENA), the first 11 projects are classified as the provincial projects. This paper will analyze the building load and energy consumption of Pingyi Science Museum, in order to conform the consumption index that suit for Shandong Province.
\end{abstract}

\section{Introduction}

Since the reform and opening policy in 1970s, the high-speed development of industry and large scale of energy consumption has brought a double crisis of haze pollution and energy shortage to the whole society which cannot be ignored. Especially in the field of architecture, the annual completed building area in China makes up about half scale of the world's building area, and a large part of which is non-energy-efficient and non-friendly-environmental buildings. Nowadays, the Chinese's government has already promulgated many regulations and specification standards for building energy efficiency and energy saving. However, compared with the buildings of developed countries in the same climatic conditions, the building heat consumption index in China was still more than 50\% higher. Ever most of China's cities has strictly executive the 65\% energy-saving standard.

It is well-known that Germany is one of the most developed countries in the world. The passive house assessment standard that established by the Passive House Institute (PHI), which is necessary and great useful for the research of buildings energy efficiency in China. At present, the foreign experts have reached a consensus that the most important part of improve energy efficiency of buildings is the passive house technology. 2014, the Passive and Low-Energy Consumption Green Building Memorandum of Understanding has made between Shandong Provincial Housing and Urban-Rural Development Bureau and Deutsche Energie-Agentur (DENA), the Pingyi Passive and Ultra Low-Energy Consumption Science Museum is classified as one of the provincial project. 


\section{Project Description and Simulation Parameters}

Pingyi Passive and Ultra Low-Energy Consumption Science Museum is one of the provincial project, it is located in the west of Binhe Road, north of Yinhua Road in Linyi City, Shandong Province. The main building function include city's urban planning, high-technology development exhibition and electronic library. The museum contains 3 floors, 5.1 meters high per each floor, frame structure and the total construction area is $5556.93 \mathrm{~m}^{2}$.

Exterior Envelope Structure: according to the thermal calculation of the building exterior envelope structure with the architecture design drawings and instructions, all the thermal parameters are meet the requirement of GB 50189-2015 “Public Building Energy Efficiency Design Standard”, see Table 1.

Table 1 Structure practice of building exterior envelope

\begin{tabular}{|c|c|c|}
\hline $\begin{array}{l}\text { Each part of exterior envelope } \\
\text { structure }\end{array}$ & Main practice & $\begin{array}{c}\text { Thermal transfer } \\
\text { coefficient }\end{array}$ \\
\hline Wall & $\begin{array}{c}\text { 220mm graphite polystyrene insulation }+200 \mathrm{~mm} \text { aerated concrete } \\
\text { block wall }\end{array}$ & $0.15 \mathrm{~W} /\left(\mathrm{m}^{2} \cdot \mathrm{K}\right)$ \\
\hline Fire barrier wall & 220mm mineral wool $+200 \mathrm{~mm}$ aerated concrete block wall & $0.20 \mathrm{~W} /\left(\mathrm{m}^{2} \cdot \mathrm{K}\right)$ \\
\hline Roof & $\begin{array}{c}\text { 250mm extruded polystyrene insulation }+120 \text { mmreinforced concrete } \\
\text { roof }\end{array}$ & $0.15 \mathrm{~W} /\left(\mathrm{m}^{2} \cdot \mathrm{K}\right)$ \\
\hline $\begin{array}{l}\text { Floor between heating AC area } \\
\text { and non-heating AC area }\end{array}$ & $\begin{array}{l}\text { 220mm extruded polystyrene insulation }+120 \mathrm{~mm} \text { reinforced concrete } \\
\text { floor }\end{array}$ & $0.15 \mathrm{~W} /\left(\mathrm{m}^{2} \cdot \mathrm{K}\right)$ \\
\hline $\begin{array}{c}\text { Partition between heating AC and } \\
\text { non-heating AC area }\end{array}$ & $\begin{array}{c}20 \mathrm{~mm} \text { adhesive polystyrene granule }+200 \mathrm{~mm} \text { aerated concrete block } \\
\text { partition }+20 \mathrm{~mm} \text { adhesive polystyrene granule }\end{array}$ & $0.65 \mathrm{~W} /\left(\mathrm{m}^{2} \cdot \mathrm{K}\right)$ \\
\hline Window & PA double low-e, radiation rate $\leq 0.25,6+12 \mathrm{Ar}+6+12 \mathrm{Ar}+6$ & $0.80 \mathrm{~W} /\left(\mathrm{m}^{2} \cdot \mathrm{K}\right)$ \\
\hline Door & Passive door & $1.00 \mathrm{~W} /\left(\mathrm{m}^{2} \cdot \mathrm{K}\right)$ \\
\hline
\end{tabular}

Basic Parameters of Main Room: according to the room function and actual use of the building, the basic parameters for each room are set up in Table 2

Table 2 Basic parameters of each room

\begin{tabular}{lcccccc}
\hline \multicolumn{1}{c}{ Room function } & $\begin{array}{c}\text { Temperature } \\
\text { range }\end{array}$ & $\begin{array}{c}\text { Relative } \\
\text { humidity }\end{array}$ & $\begin{array}{c}\text { AC } \\
\text { area }\end{array}$ & $\begin{array}{c}\text { Design } \\
\text { person }\end{array}$ & $\begin{array}{c}\text { Fresh } \\
\text { air }\end{array}$ & AC \\
\hline Planning exhibition hall 1 & $20 \sim 26$ & $40 \sim 60$ & 243.44 & 40 & 30 & yes \\
Planning exhibition hall 2 & $20 \sim 26$ & $40 \sim 60$ & 402.24 & 60 & 30 & yes \\
Planning exhibition hall 3 & $20 \sim 26$ & $40 \sim 60$ & 354.76 & 50 & 30 & yes \\
Science exhibition hall & $20 \sim 26$ & $40 \sim 60$ & 1329.62 & 80 & 30 & yes \\
Movie hall & $20 \sim 26$ & $40 \sim 60$ & 330.22 & 50 & 30 & yes \\
Monitoring office & $20 \sim 26$ & $40 \sim 60$ & 31.88 & 2 & 30 & yes \\
Leisure & $20 \sim 26$ & $40 \sim 60$ & 291.09 & 35 & 30 & yes \\
Office 1 & $20 \sim 26$ & $40 \sim 60$ & 107.59 & 4 & 30 & yes \\
Office 2 & $20 \sim 26$ & $40 \sim 60$ & 54.97 & 4 & 30 & yes \\
Office 3 & $20 \sim 26$ & $40 \sim 60$ & 51.21 & 4 & 30 & yes \\
Dinning hall & $20 \sim 26$ & $40 \sim 60$ & 291.66 & 28 & 30 & yes \\
Coffee & $20 \sim 26$ & $40 \sim 60$ & 102.67 & 8 & 30 & yes \\
Internet cafe & $20 \sim 26$ & $40 \sim 60$ & 97.73 & 10 & 30 & yes \\
\hline
\end{tabular}

Illumination, Lighting and Equipment Power density: according to the requirements from Table B.0.4-3 and B.0.4-0 on GB50189-2015 "Public Building Energy Efficiency Design Standard". The illumination (LX), lighting and equipment power density $\left(\mathrm{W} / \mathrm{m}^{2}\right)$ are shown on Table 3. 
Table 3 Illumination, lighting and equipment power density

\begin{tabular}{clccc}
\hline Category & \multicolumn{1}{c}{ Room function } & $\begin{array}{c}\text { Illumination } \\
\text { LX }\end{array}$ & $\begin{array}{c}\text { Lighting power } \\
\text { density } \\
\text { W/m }\end{array}$ & $\begin{array}{c}\text { Lighting power } \\
\text { density } \\
\text { W/m }\end{array}$ \\
\hline \multirow{5}{*}{ Public } & Planning exhibition hall & 200 & 9 & 5 \\
& Science exhibition hall, & 200 & 9 & 15 \\
movilding & General office & 300 & 8 & 15 \\
& Leisure & 300 & 9 & 0 \\
& Dinning & 200 & 9 & 2.5 \\
& Coffee & 150 & 5.5 & 2.5 \\
& Internet cage & 200 & 9 & 0 \\
\hline
\end{tabular}

Lighting, Occupancy and Equipment Usage Rate Timetable: according to the actual usage, the museum will open on Wednesday to Sunday from 9am to 17pm in summer and 9am to 16pm in winter. Monday and Tuesday will be closed for rest. During the project's simulation, the lighting, occupancy and equipment usage rate timetable will refer to the requirements from table B.0.4-4, B.0.4-6, B.0.4-10 on GB50189-2015 "Public Building Energy Efficiency Design Standard".

Air-Conditioning System: it contains fan coil and fresh air system, which will operate from November to the following February for winter heating and from June to September for summer cooling. The AC operating timetable in China is different from the foreign public buildings' timetable, it is not the 24 hours continuous operation. In this project, the AC operating time is the same as the museum working timetable.

Outdoor Design Parameters: the requirement of thermal transfer coefficient of passive ultra-low-efficiency building exterior envelope is very strictly. There is a clear indicators on the maximum heating and cooling load as well as the energy consumption technologies. This project takes the above simulation parameters, and then calculates an 8760 hours simulation model by Design Builder software to analyze the indoor environment and the air conditioning system. During the process of calculation, this model uses the Linyi city typical meteorological parameters as the basis of building load calculation. Moreover, the simulation software has fully considered the effect of wall materials on the attenuation and delay of the temperature wave.

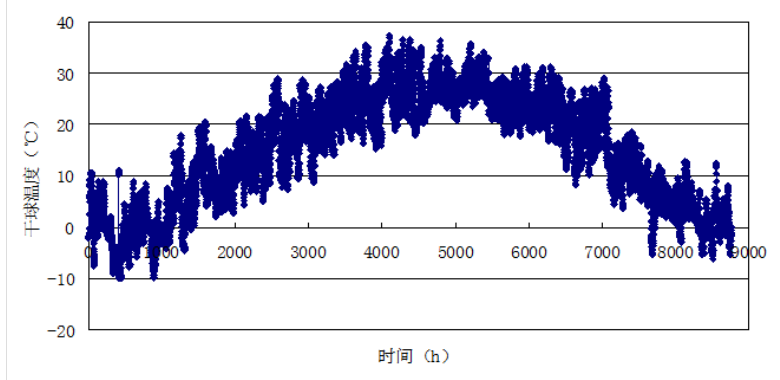

Fig. 1. Linyi typical meteorological parameters

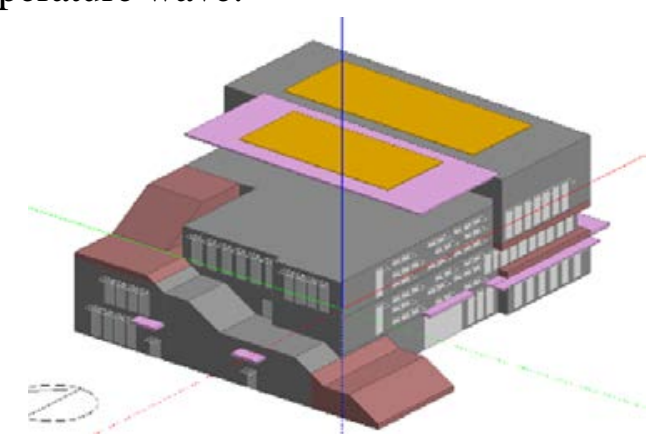

Fig. 2. 8760 hours simulation model

\section{Simulation Results}

The simulation result ignored the impact from air permeability, without considering the AV load during the transition season. The windows and doors are closed, so the impact from natural ventilation to the AC load consumption in summer can be ignored also. Simultaneously, it considered the effect of sun shading, after 8760 hours' calculating, the monthly energy consumption demand of heating and cooling load can be see Table 4. 
Table 4 Monthly energy consumption demand of heating and cooling load

\begin{tabular}{ccccc}
\hline Month & $\begin{array}{c}\text { Zone Heating } \\
\text { kWh }\end{array}$ & $\begin{array}{c}\text { Total Cooling } \\
\text { kWh }\end{array}$ & $\begin{array}{c}\text { AHU Heating } \\
\text { kWh }\end{array}$ & $\begin{array}{c}\text { Sensible Cooling } \\
\text { kWh }\end{array}$ \\
\hline January & 16288.66 & 0 & 24237.25 & 0 \\
February & 10777.87 & 0 & 13026.89 & 0 \\
March & 0 & 0 & 0 & 0 \\
April & 0 & 0 & 0 & 0 \\
May & 0 & 0 & 0 & 0 \\
June & 0 & 16698.08 & 0 & 14603.77 \\
July & 0 & 26649.32 & 0 & 14525.07 \\
August & 0 & 27541.97 & 0 & 15624.37 \\
September & 0 & 8757.32 & 0 & 6548.23 \\
October & 0 & 0 & 0 & 0 \\
November & 6690.18 & 0 & 0 & 0 \\
December & 13274.33 & 0 & 17794.25 & 0 \\
\hline
\end{tabular}

Then, according to the above simulation data, this project's building load and energy consumption are shown in the following Table 7. It is noted that all the index results are calculated with air-conditioning area. The annual maximum heating load time is 09:00 in January $19^{\text {th }}$. The annual maximum cooling load time is 09:00 in July $24^{\text {th }}$.

Table 5 Building load and energy consumption

\begin{tabular}{llllll}
\hline \multicolumn{1}{c}{ Item } & Unit & Result & & Innit & Result \\
\hline Annual maximum heating load & $\mathrm{kW}$ & 350.78 & Heating load index & $\mathrm{W} / \mathrm{m}^{2}$ & 72.69 \\
Annual maximum cooling load & $\mathrm{kW}$ & 508.97 & Cooling load index & $\mathrm{W} / \mathrm{m}^{2}$ & 105.47 \\
Annual heating energy consumption & $\mathrm{kWh}$ & 47031.04 & Annual heating energy consumption index & $\mathrm{kWh} / \mathrm{m} 2 \cdot \mathrm{a}$ & 9.75 \\
Annual cooling energy consumption & $\mathrm{kWh}$ & 79646.69 & Annual cooling energy consumption index & $\mathrm{kWh} / \mathrm{m} 2 \cdot \mathrm{a}$ & 16.50 \\
\hline
\end{tabular}

Finally, the primary energy consumption include heating, cooling and lighting is:

Table 6 Primary energy consumption

\begin{tabular}{lccc}
\hline & $\begin{array}{c}\text { Total Energy } \\
\mathrm{kWh}\end{array}$ & $\begin{array}{c}\text { Energy Per Total Building Area } \\
\mathrm{kWh} / \mathrm{m}^{2}\end{array}$ & $\begin{array}{c}\text { Energy Per Conditioned Building Area } \\
\left(\mathrm{kWh} / \mathrm{m}^{2}\right)\end{array}$ \\
\hline Total Site Energy & 247098.96 & 44.47 & 51.20 \\
Total Source Energy & 782552.92 & 140.82 & 162.16 \\
\hline
\end{tabular}

\section{Conclusion}

According to the above dynamic simulation, the annual heating energy consumption index is $9.75 \mathrm{kWh} / \mathrm{m}^{2} \cdot \mathrm{a}$, it has met the requirement of PHI limit index that is not greater than $15 \mathrm{kWh} / \mathrm{m}^{2} \cdot \mathrm{a}$. The annual cooling energy consumption index is $16.50 \mathrm{kWh} / \mathrm{m}^{2} \cdot \mathrm{a}$, which is a little higher than the limit index. However, the project's local outdoor meteorological conditions in summer is different with the conditions in Germany, this paper considered with the actual situation that the simulation results can be accepted.

Moreover, there are many China's cities have strictly executive the $75 \%$ energy-saving standard from October, 2015. Compared with 75\% energy saving standard, the passive ultra-low-energy consumption building's energy-saving rate can be reached on at least $85 \%$.

\section{Acknowledgement}

In this paper, the research was sponsored by the Key Technologies of Passive Ultra Low-Energy Consumption Green Building Research from Ministry of Housing and Urban-Rural Development of the People's Republic of China (Project No. K12015109). 


\section{References}

[1] GB50189-2015 Public Building Energy Efficiency Design Standard, [S], 2015.

[2] PHI, Passive Houses for Different Climate Zones

[3] GB37/T 2397-2013 Standard on Inspection and Evaluation of Application Projects of Renewable Energy Buildings, [S], 2013

[4] DB37/5026-2014 Design Standard for Energy Efficiency of Residential Buildings, [S], 2015

[5] Chen Yan, the Twelfth Five Year Plan to Promote the Construction of Energy Efficient Policy, [A], China’s Economic Analysis and Outlook (2010-2011), [C], 2011 